\title{
EXPENDITURE ON INNOVATIONS OF SMES AND SOURCES OF THEIR FINANCING IN POLAND AS ILLUSTRATED BY THE EXAMPLE OF MALOPOLSKIE VOIVODESHIP
}

\author{
Dagmara K. Zuzek ${ }^{1}$, PhD \\ ${ }^{1}$ Agricultural University in Cracow, Faculty of Economics, Department of Economics and Economic Policy ${ }^{2}$
}

\begin{abstract}
Due to increasing globalization, innovations have become a basic method utilized by enterprises to gain competitive advantage and improve the efficiency of operations. Their introduction is a prerequisite for the growth of any business, however, in the case of the sector of small- and medium-sized entrepreneurs, the implementation of new solutions is their way to survive. The purpose of this paper is to analyse and evaluate the expenditure made towards innovative activities of SMEs in Poland in 2012-2016. Data published by GUS (Statistics Poland) and Eurostat on innovative activities of SMEs in Poland have been used, with a special focus on the Małopolskie Voivodeship.
\end{abstract}

Key words: sector of small- and medium-sized enterprises, R\&D expenditure, innovations, sources of funding. JEL code: 032, 039, 056.

\section{Introduction}

Due to Poland's accession to the European Union, the increasing globalization and scientific and technical progress, innovativeness of enterprises has become a matter of particular importance. It should continue to steadily increase as innovations are recognized as an opportunity to meet challenges made by consumers. For that reason, research interest in innovations has not decreased as evidenced by numerous papers published in the literature. The above is reflected in the basic importance of innovativeness to the development and achievement of competitive advantage and the improved standard of living of society. The research on innovativeness requires constant activity of economic entities which not only must observe and analyse changes in their environment but must also be prepared to embrace them and become their inspirers. All such activities allow to adapt to the ever-changing environment, respond to its needs and create changes which, in turn, enables them to create their competitive advantage. Currently, innovations are major factors determining a country's social and economic development and a driving force of the entire economy. That is why efforts to introduce innovations can be seen in all branches of the economy. Innovations have undoubtedly become both the sign and the requirement of the modern-day civilization progress.

The strategic and multidimensional nature of innovations stems from their variability and a growing pace of such changes, dynamism and connection of the enterprise and its future, the mutual synergic pervasion and, finally, their economic effectiveness. The intensification of innovative decisions is the product of many variables. Innovative decisions are one of basic sources of gaining a competitive advantage by enterprises, especially SMEs which, to grow, need innovations such as new products or services, new technologies, organization systems and new markets.

The purpose of the paper is to assess the condition of the investment expenditure on innovations at small- and medium-sized enterprises in Poland with a special focus on the Malopolskie Voivodeship. This paper relies on secondary data published in GUS Statistical Yearbooks and Eurostat data. Based thereon the dynamics of changes in 2012-2016 has been presented, including both industrial and service enterprises.

\footnotetext{
${ }^{1}$ Author: Tel.: +48 126623452; fax: +48 126623452, E-mail address: dagzuz@gmail.com 2 The publication was financed from subsidies for maintenance of research potential granted by Ministry of Science and Higher Education
} 


\section{Innovativeness as an opportunity for competitiveness of entrepreneurs}

The basic purpose for which innovations have been implemented by enterprises, especially SMEs, is the pursuit of the competitive advantage on the market. The process of constant improvements in the area of the management of enterprises indicates a broad range of activities that are required to be implemented to gain such level of competitiveness that allows a company to gain a strong market position (W. M. Grudzewski, I. K. Hejduk). The above, however, requires the application of various concepts, methods or techniques of the organization and management of an enterprise (D. Zuzek. L. Paluch 2016; D. K. Zuzek, I. Wielewska 2017; I. Wielewska 2017).

From the economic perspective, the most important business innovations should be those innovations that are of strategic importance, ensuring stable development in the long run. Thus, access to IT infrastructure, the quality of labour force (education, mobility) and technical and technological development should be regarded as vital aspects. That is why scientific and innovative policy plays a very important role in the enterprises' impact on social and economic growth.

In order to operate on the European Union market, SMEs face high demands as regards the introduction of innovations. Adapting to the ever-changing customer expectations and fast-paced technical and technological progress are key to attain a significant market position and can be possible through the intensification of innovations leading to their improved effectiveness and competitiveness. SMEs attach special importance to attaining best performance levels by sourcing properly qualified staff, proper co-operation with the immediate and external surroundings, and implementing effective production methods responding to market needs. Such factors may build the image of innovative enterprises and at the same time be their strengths of their operations on a global market.

The innovativeness of enterprises depends on a number of factors determining its scope and level and the following may be regarded as major innovation and competitiveness factors (J. Pawlowski 2005):

- the capacity to invent, create and engage in innovations;

- the capacity to absorb innovations;

- the structural capacity to strengthen a competitive position, namely, the potential to increase a market share related to technical and organizational infrastructure;

- competences of the development of product innovativeness and assortment based on technical and technological as well as financial potential;

- the innovation capacity of the technical and technological potential being the degree of attractiveness and innovativeness of technical and technological means;

- the capacity to finance innovative activities and activities fostering competitiveness on the market. Modern small- and medium-sized enterprises should be innovative and one should remember that a business can be regarded as innovative if (A. Jasinski 2005):

- it has been engaged in a wide range of R\&D works or has been relying on the results of such works performed externally;

- it has spent relatively large expenditure on innovations;

- it has been regularly implementing new scientific and technical solutions;

- the proportion of innovations in production or services is high;

- it has been regularly creating and introducing innovations into production, work organization and the market. 
However, attention should be had to the fact that frequently innovative activities of SMEs are not based on developing new products or technologies as in the case of large companies. Due to financial limits, they are not engaged in their own large-scale research. Their innovations are strictly related to market needs and the needs of their potential customers and users, and involve popularization of new product and technological solutions created by large entities and research institutions in that way fuelling faster economic growth.

\section{Expenditure on innovations at SMEs}

Polish SMEs have been more and more innovative and have been actively engaged in R\&D works and increasingly interested in partnerships. The above is also applicable to the growing tendency among entrepreneurs to take risk being an inseparable part of innovations. Entrepreneurs see benefits that stem from innovations and have been more and more active in that field, although there is still much room for improvement as regards the sphere of R\&D and innovations.

Research and development expenditure to GDP is regarded as one of key measures of the economy's innovativeness and technological progress. In Poland the growth rate of R\&D expenditure is usually higher than the GDP growth rate, however, it is still insufficient (Table 1).

Table 1

GDP and R\&D expenditure growth rates in Poland in 2012-2016*

\begin{tabular}{|l|c|c|c|c|c|}
\hline \multicolumn{1}{|c|}{ Indicator } & $\mathbf{2 0 1 2}$ & $\mathbf{2 0 1 3}$ & $\mathbf{2 0 1 4}$ & $\mathbf{2 0 1 5}$ & $\mathbf{2 0 1 6}$ \\
\hline GDP growth rate & 101.6 & 101.4 & 103.3 & 103.9 & 103.3 \\
\hline R\&D expenditures & 122.8 & 100.5 & 112.1 & 111.7 & 95.28 \\
\hline
\end{tabular}

*Previous year $=100$

Source: 2012-2016 data by GUS, Warsaw

The above is also confirmed by data pertaining to EU member states. Poland's rate (approx. 1 \% GDP) is clearly below the average EU rate (2.03\%). On the other hand, the steadily growing R\&D expenditure of SMEs is promising. In 2016 the sector invested, in nominal terms, an amount which was more than four times larger vis-à-vis 2010 and its share in total R\&D expenditure amounted to $65.7 \%$ (in 2010 - $26.6 \%$ ). Compared to other EU member states, BERD being the percentage of GDP was higher in Poland than in Portugal, Slovakia and Latvia (BERD in Latvia was the lowest) (Przedsiebiorczosc w Polsce /Entrepreneurship in Poland, 2018).

In 2018, Poland ranked $25^{\text {th }}$ in the European Innovation Scoreboard among the so-called moderate innovators. The strengths of the innovation-friendly environment as per the ranking included broadband penetration and entrepreneurship whereas innovators and attractive research systems were the weakest innovation dimensions (https://polska.pl/economy/investmentsprojects/poland-climbs-39th-position-global-innovation-index/). On the other hand, in the 2018 Global Innovation Index1 report Poland ranked 39 out of 126 countries, right behind Bulgaria, Slovakia and Latvia, with Switzerland, Holland and Sweden as the ranking's leaders (https://polska.pl/economy/investments-projects/poland-climbs-39th-position-global-innovationindex/).

A growing number of entrepreneurs have been engaged in innovations and the share of innovative enterprises in industry has been steadily increasing since 2012. Current data pertaining to innovations by enterprises in 2014-2016 show that the share of innovative businesses stood at $18.7 \%$ in industry (the increase by 1.1 percentage point $y$-on-y) and $13.6 \%$ in services (the increase 
by 3.8 percentage points $y$-on-y). Increases were also seen among innovation active enterprises. In 2014-2016 industrial and service innovation active enterprise accounted for $20.3 \%$ and $14.5 \%$ of a total number of such entities, respectively (vis-a-vis $18.9 \%$ and $10.6 \%$ in 2013-2015, respectively) (Przedsiębiorczosc w Polsce, 2018).

The level of innovativeness of enterprises mostly depends on the choice and structure of tools and instruments of the innovation policy. Changes made by entrepreneurs allow to identify vital components of the model of an innovation process with the integration of varied and extensive market relations and flexible adaptation to market requirements and possibilities of organization by the process of continuous innovation being its indispensable elements, i.e. regular product and service modification. Major reasons why the Polish innovation policy was poorly rated include (Warunki zdynamizowania innowacji w polskich przedsiebiorstwach.....):

- an incompatible government strategy as regards the development of technical and technological solutions or industrial policy,

- taking basic decisions regarding the directions of the industry development which do not always account for the goals of the entire economy,

- insufficient financial R\&D expenditure,

- poor co-operation between Polish scientific and research units and industrial enterprises with research centers and foreign industrial enterprises,

- inaccurate and unstable legislation.

Ineffective domestic innovation policy is the result of the weakness of individual segments of the domestic innovation system and little connection between them (the size and structure of innovation expenditure, a tax policy, an intellectual property protection system, a competition policy, a system of legal norms). Institutions supporting those activities and creating legal and institutional solutions should develop a new culture incorporating values and attitudes such as entrepreneurship, creativity, expertise, activity, professionalism, the involvement in activities of organizations, the acquisition of new qualifications and skills with the use of new technologies. A major barrier includes low financial outlays on innovations which, during the final period of transformation, practically continue to be invariably low (relative to GDP). Moreover, an important disadvantage of the subject structure of R\&D works carried out in Poland is a relatively high share of basic research via-a-vis applied research and development works. That results in little chance of joint research by entrepreneurs and higher education units focused on basic research. Poland lacks sufficient concentration of investment outlays (on a small scale) on selected fields of knowledge and technology which leads to their dispersion in various areas, resulting in, in turn, failure to create an expected synergy effect, unlike in, for example, Finland or Ireland (Wisniewska, J., Janasz K., 2018).

Innovations among enterprises mean engaging in different types of activities facilitating their implementation and incurring the related expenditure. For years Poland has had a low proportion of innovative enterprises, both in the industrial and service sectors. Over the past few years it did not increase significantly in industry, and in the service sector, after a few years of decline, No increase was recorded until 2016 (table no. 2). Even though the data shows that the share of innovative enterprises has been increasing gradually, it still remains unsatisfactory. 
Innovative enterprises in Poland in 2012-2016 [in \%]

\begin{tabular}{|c|c|c|c|c|c|c|}
\hline \multirow{2}{*}{$\begin{array}{l}\text { Innovative } \\
\text { enterprises }\end{array}$} & \multirow{2}{*}{ Innovation types } & \multicolumn{5}{|c|}{ Years } \\
\hline & & 2012 & 2013 & 2014 & 2015 & 2016 \\
\hline Industry & \multirow{2}{*}{ Overall } & 16.51 & 17.13 & 17.52 & 17.58 & 18.7 \\
\hline Services & & 12.38 & 11.41 & 11.41 & 9.79 & 13.6 \\
\hline Industry & \multirow{2}{*}{ Product } & 11.19 & 11.01 & 11.72 & 11.77 & 12.4 \\
\hline Services & & 7.05 & 5.81 & 6.78 & 4.82 & 6.9 \\
\hline Industry & \multirow{2}{*}{ Process } & 12.44 & 12.82 & 12.95 & 13.03 & 15.2 \\
\hline Services & & 9.11 & 8.50 & 8.39 & 7.39 & 10.4 \\
\hline
\end{tabular}

Sources: Data by GUS 2012-2016, Warsaw

Based on the analysis of the data in the table, although the percentage of innovative enterprises in industry went up by $13.3 \%$ in total over the entire period under analysis (the highest increase was recorded in 2016), in the case of enterprises engaged in rendering services, until 2015 basically a downward trend had been observed (a decline by as much as $21 \%$ ) which continued until 2016.

Over the past few years a change in the structure of expenses related to innovations was visible, both in regard of Poland and the Malopolskie Voivodeship. In 2007 the vast majority of expenses of enterprises engaged in industrial processing was spent on investments - on average industrial enterprises spent $85 \%$ of funds on investments and in the Malopolska Voivodeship the average investment expenditure totaled $79 \%$. Such structure of expenditure is characteristic of regions which are less developed in terms of innovations.

2016 witnessed a change of the structure of expenditure both in Poland and especially in the Malopolska region. The share of expenditure on investments in tangibles in total innovation expenditure of industrial processing enterprises diminished (Poland - $77 \%$; Malopolska - $68 \%$ ), while the share of R\&D expenditure rose (up to $18.5 \%$ and $31 \%$, respectively). The above may prove that the investments of industrial enterprises in tangibles rose which led to the shift in the structure of expenditure. Such direction of changes may be the effect of the domestic and regional policy of supporting innovations of enterprises financed mostly with European Funds until 2020 focusing on R\&D works. The above is particularly noticeable in the case of the following voivodeships: Lubelskie, Podkarpackie and Swiętokrzyskie (covered by the Eastern Poland Program 2014-2020), which, compared to other voiovodeships, stand out thanks to the relatively higher share of $R \& D$ expenditure (Aktualizacja pogłebionej diagnozy innowacyjnosci..... 2018).

As regards Poland's GERD, its value slightly diminished in 2015-2016. In the case of the Małopolskie Voivodweship, the situation is different and showed an upward trend. GERD rose particularly sharply between 2015 and 2016, i.e. by $48 \%$. Even a sharper rise has been seen in regard of BERD - between 2015 and 2016 in the Malopolska region it went up by $150 \%$. Such sharp rise results from the significant increase of R\&D expenditure (overall and in the case of enterprises, as well) with the voivodeship's insignificant rise of GDP. One of reasons of such sharp rise of the expenditure is the fact that in 2016 the entities seated in the Malopolskie Voivodeship obtained the highest amount of Smart Growth Operational Program (POIR) funds - the value of funding agreements in Malopolska amounted to EUR $133.58 \mathrm{~m}$, i.e. $8 \%$ more compared to the Mazovian Voivodeship which ranked second (Aktualizacja pogłebionej diagnozy innowacyjnosci.... 2018).

It is a positive phenomenon in the context of the region's innovativeness. It should be noted in that context that GERD is also affected by expenditures incurred by research units whose saturation 
(both in the Malopolskie and Mazowieckie Voivodeships that are in the lead in terms of the value of that rate) is high.

Compared to the EU average and selected regions, the Malopolskie Voivodeship's R\&D expenditure was much lower until 2015. In 2016 total R\&D expenditure and the R\&D expenditure of the sector of enterprises rose significantly and slightly exceeded the EU average. In 2016 Malopolska's GERD was $22 \%$ higher vis-a-vis the EU average and in 2016 BERD was $25 \%$ higher.

Malopolska's R\&D expenditure per capita has also demonstrated an upward trend. Between 2007 and 2015 it rose by EUR 88, namely, the increase by $250 \%$. Average R\&D expenditure per capita is $34 \%$ higher than the domestic average, however, it accounts for nearly $50 \%$ of the analogical expenditure recorded for the Mazovian Voivodeship. Given the 2016 data, it should be expected that the trend will be upward (Aktualizacja pogłebionej diagnozy innowacyjnosci.... 2018).

As regards the comparison of average R\&D expenditure incurred by the Malopolska region and selected European regions in EUR (per capita) in 2007-2015, it is not so favorable. The expenditure of the Malopolska region in 2015 was 3.9 times lower than the average EU expenditure, but at the same time such difference has been diminishing year by year. On the other hand, the expenditure incurred by the Malopolska region has been increasing at a faster pace than in the European Union. Although slow in general, those changes have been showing an upward trend which has a positive effect on the increase of the region's innovations.

\section{Conclusions, proposals, recommendations}

The increasing innovation expenditure recorded in the case of Polish SMEs is an opportunity to accelerate Poland's economic growth. The analysis of the structure and dynamics of the innovation expenditure showed that it is small industrial enterprises that have been investing in innovations and regularly increasing their innovation expenditure.

SMEs have seen that the Polish economy has large innovation potential and possible R\&D activities that can be undertaken by them have significant impact on the development of modern product and process solutions and the scale of expenditure made towards innovations.

1) The change of the structure of expenses towards innovations in Poland has been observed for a few years, especially in the case of industrial processing enterprises- on average $85 \%$ of the expenditure and in the case of the Malopolska region - $79 \%$.

2) The Malopolska region's R\&D expenditure per capita continues to grow. In $2007-2015$, that figure was EUR 88 higher (the rise by $250 \%$ ).

3) Average R\&D expenditure per capita of the Malopolskie Voivodeship is $34 \%$ higher than the average figure in Poland, however, it accounts for less than $50 \%$ of the analogical expenditure recorded by the Mazowieckie Voivodeship.

\section{Bibliography}

1. Grudzewski, W. M., Hejduk, I. K. (2004). Metody projektowania systemów zarządzania (Methods of designing management systems). Difin. Warszawa

2. Jasiński, A. (1995). Przedsiębiorstwo innowacyjne na rynku (An innovative enterprise on the market), "Marketing i Rynek" (Marketing and the Market). No 3, pp. 2.

3. Pawłowski, J. (2005). Diagnoza potencjału innowacyjności i konkurencyjności przedsiębiorstw (Diagnosis of enterprises' innovativeness and competitiveness potential). „Przegląd Organizacji”. pp. 5- 29.

4. Poland climbs to 39th position in Global Innovation Index, Access: https://polska.pl/economy/investmentsprojects/poland-climbs-39th-position-global-innovation-index/. Retrieved: 28.12.2018

5. Przedsiębiorczość w Polsce (Entrepreneurship in Poland). (2018). Ministerstwo Przedsiębiorczości i Technologii (the Ministry of Entrepreneurship and Technology) 
6. Warunki zdynamizowania innowacji w polskich przedsiębiorstwach przemysłowych. Raport z realizacji grantu Narodowego Centrum Nauki w Krakowie.(Conditions of the dynamization of innovations in Polish industrial enterprises. A report on the implementation of a grant by the National Science Center) K. Poznańska i S. Sudoł (red.). 2016. Wyd. Wyższej Szkoły Menedżerskiej w Warszawie im. Prof. L.J. Krzyżanowskiego, Warszawa

7. Wielewska, I., (2017). Eco-innovations and sustainable development of businesses in rural areas of Kujawsko-pomorskie Province of Poland [in:] Economic Science for Rural Development. Proceedings of the International Scientific Conference, No 44, Latvia University of Agriculture, Jelgava, pp. 205-211.

8. Zuzek, D. K., Wielewska, I. (2017). Rola innowacji w generowaniu przewagi konkurencyjnej małych i średnich przedsiębiorstw $\mathrm{w}$ regionie małopolskim (The role of innovation in generating the competiveness of small and medium enterprises in malopolska region) [in:] Marketing i Rynek, No 10, pp. 798-807.

9. Zuzek, D., Paluch, Ł. (2016). Wpływ działalności innowacyjnej na konkurencyjność sektora MSP w Polsce (The impact of innovative activities on competitiveness of the SMEs sector in Poland). Marketing i Rynek, no10, pp. $632-642$. 